\title{
THE INFLUENCE OF CINEMA AND TELEVISION ON TOURISM PROMOTION
}

\author{
Raquel Sola Real y Claudia Medina Herrera \\ Universidad de La Laguna
}

\section{Abstract}

In a world where television and cinema productions are becoming more and more alluring, the power of attraction that they can exert over people is unquestionable. This work revolves around the previous idea, going through countries that have benefited from film-induced tourism -from the USA to the UK, without forgetting New Zealand. After explaining new emerging forms of marketing related to this kind of tourism (place branding), we end up analyzing the past and current situation of shootings in Spain, and more specifically, in the Canary Islands.

KeYwords: Film-induced tourism, place branding, shootings in Spain, shootings in the Canary Islands.

\section{LA INFLUENCIA DEL CINE Y LA TELEVISIÓN EN LA PROMOCIÓN TURÍSTICA}

\section{RESUMEN}

En un mundo donde las producciones televisivas y cinematográficas son cada vez más fascinantes, es incuestionable el poder de atracción que estas ejercen sobre las personas. Este trabajo gira en torno a esa idea, examinando la situación de diferentes países que se han beneficiado del turismo cinematográfico: desde Estados Unidos hasta Reino Unido, sin olvidarnos de Nueva Zelanda. Tras explicar nuevas formas de marketing relacionadas con este tipo de turismo como el place branding, terminaremos analizando el pasado y presente de España y las Islas Canarias en cuanto a rodajes y situación audiovisual se refiere.

Palabras Clave: turismo cinematográfico, place branding, rodajes en España, rodajes en las Islas Canarias. 


\section{OBJECTIVES}

Regarding the objectives of the work, we can name at least five main purposes that we wanted to achieve:

1) To analyze and clarify the relation between cinema and tourism through history.

2) To explain what makes a spectator want to visit a destination that appears in films or TV series.

3) Prove that cinema and television productions are able to attract and generate tourism on their own.

4) Understand how tourist promotion occurs through motion pictures.

5) Evaluate the situation and the possibilities in Spain and the Canaries.

\section{INTRODUCTION}

UNWTO (World Tourism Organization) defines tourism as the action that "comprises the activities of persons traveling to and staying in places outside their usual environment for not more than one consecutive year for leisure, business and other purposes" (Tourism Satellite Account..., 2011: 1).

Therefore, there are different kinds of tourists: as the definition above declares, many people travel because of business, others do it because they want to meet their family or friends, and others go to places in order to enjoy a variety of leisure activities. In this category we can find the so-called "sun, sea and sand" tourism or cultural tourism, among others.

It is no novelty to state that in the last years there has been an increase in the number of people who travel to experience something and not just to stay somewhere -tourist motivation is one of the most intricate and difficult areas of tourism research, as explained in the book Consumer psychology of tourism, hospitality and leisure (2004). Due to the fact that there are a great variety of different tourists, the motivation of each one of them is also different and it is tied to psychological factors and/or social forces. It is also clear, as asserted in the book, that in many cases people are not willing to reveal the reason for their travel, or sometimes they are not even sure they know it and therefore they are unable to express it.

Nevertheless, there is one motivation that stands out among the different ones revealed by a wide range of authors. As Richard Sharpley and David J. Telfer gathered in the book Tourist and Development: Concept and Issues (2002), several authors (van Rekom, Krippendorf) claim that one of the main reasons to travel is to escape from reality, to elude day-to-day problems and to feel and experience something special.

After knowing this fact, it comes as no surprise that certain types of tourism are becoming more and more relevant in the last few years: such is the case of slow tourism, dark tourism or film-induced tourism, the latter being the subject of our study.

We cannot forget that cinema is born absolutely linked to the concept of travel in the sense that first films, visiting distant places or recognized celebrations, 
were inviting the viewer in the dark room to fly and enjoy the destination seen. Besides, both movies and tourism were invented during the 19th Century, when Thomas Cook organized his first tour and the first Lumière's projection took place.

At this point we have already established that people are pursuing new realities different from their own, and as time passes that claim has become indisputable for the tourism industry.

When a product gain a meaningful popular diffusion like in the case of Game of Thrones, Harry Potter or The Lord of the Rings, the number of visits to their filming locations keep rising no end. That is the case of Kings Landing (Dubrovnik, Croatia), Middle Earth (Mangaotaki Rocks, New Zealand), Hobbiton (Matamata, NZ) or The Wizarding World of Harry Potter (Universal Studios, Florida or Warner Bros Studios, London). Fans have set up a new type of tourism and a new type of tourist, the currently known as jet setters. These adepts are voluntary spending much more money just to satisfy, not only their cinematographic whims, but also their television ones, as we are living in the Golden age of TV series. It is an opportunity that in the first two decades of the 21 st century is being taken seriously into consideration.

Film-induced tourism (also known as movie tourism or screen tourism) is defined as "the visit to a destination or attraction as a result of the place being featured on television, a video, or the cinema screen" (Hudson and Ritchie, 2006a: 387-396). We can find different reasons that support the rise of this kind of tourism, but two of the most important are the improvement of international travel and the growth of the entertainment industry (Hudson \& Ritchie, 2006b: 256-268).

Film-induced tourism also shares characteristics with another type of tourism that is close related to cinema: literary tourism. As Pocock explains in Catherine Cookson Country: Tourist Expectation and Experience (1992: 236-243), literature can also make people desire to live and get to know another reality.

Therefore, despite being different, literary tourism can be considered an antecedent of film tourism (Connell, 2012: 1007), since both share some similarities: the narrative can stir up emotions in the reader/viewer and it also creates a bond through the plot and personal circumstances or aesthetic sensibility. We should also take into account the amount of books that end up being adapted to films.

\begin{tabular}{|c|c|c|}
\hline \multicolumn{3}{|c|}{ LITERARY TOURISM VS FILM-INDUCED TOURISM (HOFFMAN, 2015: 61) } \\
\hline $\begin{array}{l}\text { Aspects Under } \\
\text { Consideration }\end{array}$ & Literary TOUrism & FILM-INDUCED TOURISM \\
\hline History & $\begin{array}{l}\text { Early forms since the Classical Era defi- } \\
\text { nitely occirring in its present form since } \\
\text { the early } 16^{\text {th }} \text { century Grand Tour }\end{array}$ & $\begin{array}{l}\text { First film productions from } 1896 \text { defi- } \\
\text { nitely occurring since the early } 1930 \text { s } \\
\text { with movies such as The Mutiny on the } \\
\text { Bounty (1935) }\end{array}$ \\
\hline $\begin{array}{l}\text { Media (armchair } \\
\text { travel by reading or } \\
\text { viewing) }\end{array}$ & $\begin{array}{l}\text { Novels, plays, poems, e-books, graphic } \\
\text { novels, bographies/autobiographies, } \\
\text { travel writing, guide books }\end{array}$ & $\begin{array}{l}\text { Cinema, television. IMAX. VHS/DVD/ } \\
\text { Blu-Ray, Internet }\end{array}$ \\
\hline Aspects of Interest & $\begin{array}{l}\text { Places, events and activities associated } \\
\text { with authors and their literary works }\end{array}$ & $\begin{array}{l}\text { Places, events, activities and people asso- } \\
\text { ciated with films and celebrities }\end{array}$ \\
\hline
\end{tabular}




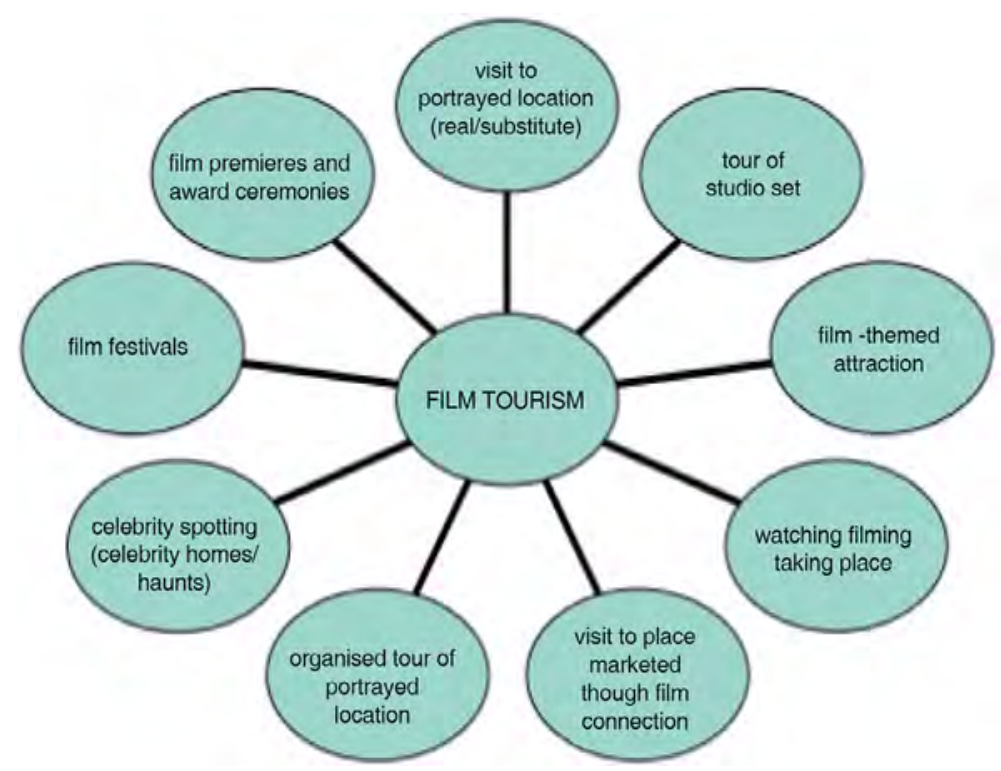

Joanne Connell / Tourism Management 33 (2012) 1007-1029.

\begin{tabular}{|c|c|c|}
\hline \multicolumn{3}{|c|}{ LITERARY TOURISM VS FILM-INDUCED TOURISM (HOFFMAN, 2015: 61) } \\
\hline $\begin{array}{l}\text { Aspects Under } \\
\text { Consideration }\end{array}$ & Literary Tourism & Film-induced TOURISM \\
\hline Macro-riche & Heritage and Cultural Tourism & Heritage and Cultural Tourism \\
\hline Type of tourism & $\begin{array}{l}\text { Postmodern - boundaries between } \\
\text { fiction and reality are blurred: fusion of } \\
\text { real world of authors and literay works } \\
\text { vs. imagined stories }\end{array}$ & $\begin{array}{l}\text { Postmodern - boundaries between fiction } \\
\text { and reality are blurred: actual place of } \\
\text { filming vs. fictional story and setting } \\
\text { portrayed in film }\end{array}$ \\
\hline $\begin{array}{l}\text { Places/people } \\
\text { associated with niche } \\
\text { tourism }\end{array}$ & $\begin{array}{l}\text { Places mentioned/depicted in books, } \\
\text { houses of writers or characters ofl } \\
\text { books, graves ot writers literary lands- } \\
\text { capes of inspiration to authors, heritage } \\
\text { sites, museums monuments, commemo- } \\
\text { rative plaques and statues }\end{array}$ & $\begin{array}{l}\text { Film locations, scenery, heritage sites, } \\
\text { film sets, celebrities or characters featu- } \\
\text { red in films (fandom), stand-in locations }\end{array}$ \\
\hline $\begin{array}{l}\text { Purpose-built } \\
\text { attractions }\end{array}$ & Theme parks & $\begin{array}{l}\text { Film studios, theme parks, film produc- } \\
\text { tion centers or workshops, constructed } \\
\text { film attractions }\end{array}$ \\
\hline
\end{tabular}

As we have already pointed out, the table above indicates that one of the aspects that link these two types of tourism is indeed the need to escape. Nevertheless, it is obvious that literature depends more on psychological factors and on the imagination of the reader -they are the ones that have to breathe life to the story.

Most papers refer only to cinema when talking about film-induced tourism, but we cannot deny the importance that TV series have been gaining throughout 
the years. After the first two golden ages of TV (from 1940 to 1955 and from 1990 to 2000), now we find ourselves in a situation where people are constantly comparing cinema with TV shows, and it is not uncommon to find regular audience and experienced journalists believing that the latter are even better. This owes to its long storytelling and therefore the bond with the characters, its originality (far from the usual cinema blockbusters), the freedom of writers and actors, since they are able to take risks, and the customized service offered by the streaming platforms -TV shows have become a social phenomenon in its own right (Wojcik, 2012: 1).

\section{BACKGROUND}

It is true that this kind of tourism may appear as a novelty to some people but, much to the contrary, it has been ongoing in some countries for quite some time now.

As Gerben Bakker explains in The Economic History of the International Film Industry (2008: 1): "from the 1910s onwards, each year billions of cinema-tickets were sold. In Italy the film industry was the fourth-largest export industry before the First World War. In the depression-struck U.S., film was the tenth most profitable industry, and in 1930s France it was the fastest-growing industry, followed by paper and electricity, while in Britain the number of cinema-tickets sold rose to almost one billion a year."

It is difficult to establish and analyze the history of film-induced tourism, since there is insufficient information about this phenomenon simply because, until recent times, nobody had considered movies as an enticer for tourists to visit a given destination and, consequently, no reliable surveys had been taken. Nonetheless, some authors indicate that it was from 1932 to 1946, during Hollywood's golden age, that people started traveling to places motivated by films, especially blockbusters (Hoffman, 2015: 81-83). The fact that air travel was improved, along with the better communication, the package tours and the new conception of holidays just helped to develop this tourism. In any case, it is only recently, over the last couple of decades roughly speaking, that reliable data have been collected.

Focusing on the present situation, in 2012 the Tourism Competitive Intelligence reported that " 40 million international tourists chose a destination primarily because they saw a film shot in that country, and up to $10 \%$ of the tourists also said movies are a factor when deciding their destination" (Cooper, 2015).

\subsection{The United States}

After doing some research, we have found that each State of the country has hosted the production of at least one movie that was relevant in terms of tourist attraction. To name a few examples, we have found astonishing information about The Goonies (whose house had to be closed after receiving 1500 visitors daily since the city tried to increase the tourism trade) (Dean, 2015); A River Runs Through It 
(which is still relevant after 20 years and had a huge impact on fishing: the industry experienced a 60 percent increase in 1992, the year the movie came out, and then grew by another 60 percent in 1993 (Devlin, 2012); Sex and The City is another example as now people travel to take a photo in Carrie's (Sarah Jessica Parker) house or to have lunch in the group favorite restaurant in Manhattan; Dances with Wolves (25\% increase compared to $7 \%$ in the previous 4 years), Deliverance (20,000 film tourists a year, gross revenue $\$ 2$ to 3 million), Close Encounters of the Third Kind (75\% increase in 1975 in Wyoming, 20\% visit now because of the film), or Last of the Mohicans (25\% increase year after release) (Turismo cinematografico..., 2013).

Taking these examples into account we visited the official tourism sites of the 50 states of the USA: apart from the best known places within the industry (California, NY), there are many of them that promote directly film/TV series activities -websites that link particular films to their film locations is a very effective promotional tool to induce tourists to the destination (Croy \& Walker, 2003: 115-133). If not, at least they add something regarding this kind of tourism on the "trip ideas" section, which can attract new visitors in the long run or even capture people who were not interested in the beginning.

\subsection{The United Kingdom \& Ireland}

The UK is probably the second country that comes to mind when thinking about places that develop TV and film productions, maybe along with Ireland.

According to the Olsberg $\bullet$ SPI consultancy, "screen tourists brought to the UK between $£ 100$ million- $£ 140$ million to the economy in 2014 , and the most popular locations can attract up to $£ 1.6$ million every year from international tourists" (Film Tourist Research, 2015).

So, in this case, there are also a great number of examples in recent history. To highlight but a few, the film Braveheart (1995) boosted tourism in Scotland, providing $£ 15$ million in additional tourist revenue, Rosslyn Chapel from The Da Vinci Code received 9500 visitors after the release of the book and the number went up to nearly 130000 visitors when it was featured in the film in 2006 (Turismo cinematográfico..., 2013).

According to the director manager of VisitBritain, Laurence Bresh, the film Pride \& Prejudice (2005), the well-known Jane Austen adaptation, caused an increase of 10000 extra visitors after release in Basildon Park, as well as 2000 additional visits to Stamford Village (Bresh, 2009).

Of course we cannot forget the biggest phenomenon in the UK, Harry Potter. Many different places throughout the entire UK have benefited from the huge success. Gloucester Cathed ral recorded an increase of $50 \%$ in one single year, Alnwick Castle visits grew up 120\% since being used as Hogwarts, and Locock Abbey increased the number of visits to more than 90,000 (not only because of Harry Potter but also thanks to The Other Boleyn Girl and Pride and Prejudice) (Stately Attraction..., 2007). 


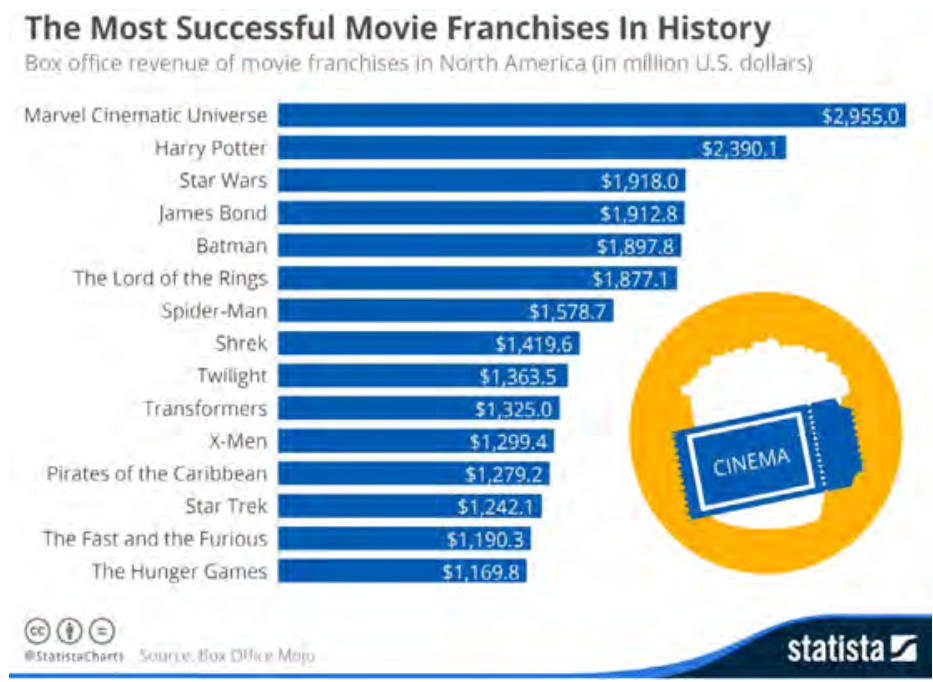

The Most Successful Movie Franchises (McCarty, 2015).

\begin{tabular}{|c|c|c|}
\hline \multicolumn{3}{|c|}{$\begin{array}{l}\text { TOTAL ANNUAL VALUE OF DOMESTIC AND INTERNATIONAL TOURISTS (£MILLION) } \\
\text { IN SEVERAL LOCATIONS THROUGH THE UK (FILM TOURIST RESEARCH, 2015) }\end{array}$} \\
\hline LOCATION & FiLm / TV Drama & $\begin{array}{l}\text { Total ANNUAL Value } \\
\text { OF DOMESTIC AND INTERNA- } \\
\text { TIONAL TOURISTS - EMILLION }\end{array}$ \\
\hline Alnwick Castle & $\begin{array}{l}\text { Harry Potter and the Philosopher's Stone (2001), Harry } \\
\text { Potter and the Chamber of Secrets (2002) }\end{array}$ & 4.3 \\
\hline Bampton & Downton Abbey (2010-present) & 2.7 \\
\hline Castle Howard & $\begin{array}{l}\text { Brideshead Revisited ( } 2008 \text { film) Brideshead Revisited } \\
\text { (1981 television series), Death Comes to Pemberley } \\
\text { (2013) }\end{array}$ & 0.4 \\
\hline Holkham & Shakespeare in Love (1998), The Duchess (2008) & 0.9 \\
\hline Lyme Mark & $\begin{array}{l}\text { The Awakening (2011) } \\
\text { Pride and Prejudice (199s television series) } \\
\text { Casanova (2005), The Village (2013-2014) }\end{array}$ & 0.9 \\
\hline Puzzlewood & $\begin{array}{l}\text { Jack the Giant Slayer (2013) Da Vinci's Demons } \\
\text { (2013-present), Doctor Who (1963-present), Merlin } \\
\text { (2008-2012) }\end{array}$ & 0.1 \\
\hline West Bay & Broadchurch (2013-present) & 1 \\
\hline Wollaton Hall & The Dark Knight Rises (2012) & 0.1 \\
\hline
\end{tabular}

Warner Bros Studios Harry Potter tour had $£ 83.4$ million in 2013 revenue, and it keeps growing up. In general, we can agree that it is the most successful franchise in the country and the second in the whole world, as we can see in the image 
on the previous page. Only in 2005 a survey by Halifax Travel Insurance showed that $16 \%$ of tourism was drawn by Harry Potter (Sylt, 2014).

We have also found more recent examples of locations that have benefited from being featured in TV series: since Broadchurch premiered in 2013, 80\% of businesses around West Bay and nearby Bridgport have reported an increase in customs (Warren, 2015). Downton Abbey could be another example, for Highclere Castle receives now 1,500 visitors per day (Haughney, 2013), as well as Outlander (Preston Mill experienced in 2015 a 26\% increase in numbers compared to the previous 12-month period, and other locations such as Doune Castle and Blackness Castle also witnessed a growth of visitors) (Lennon, 2015), or the 2015 adaptation of Poldark (50\% increase in visitors to the National Trust's Levant mine) (Poldark's Levant Mine..., 2017).

\subsection{Sweden \& Denmark}

When thinking about TV productions in Europe, we usually tend to be aware first of the UK or Ireland. However, in the last few years, there has been an increase of people traveling to Scandinavian countries due to the rise of the "Nordic noir" phenomenon - the genre that comprises the crime fiction written (and now also filmed) in Scandinavia. Following the previous methodology, we searched for information on the official tourism websites of the countries to prove that they are well aware of what they can offer and of how they can attract people, since we came across a number of tours and itineraries.

In this case we should take into account that most of the locations that we are going to name were featured in books first, so there is no clear separation between tourists that got to know the places by reading and the ones that grew aware of them by watching their subsequent screen productions. But, as we stated above, both literature and screen tourism can be related and this can be a great example of that.

Although Stockholm draws lots of tourists and it is difficult to measure the impact of a film in itself, there are some figures that show the importance of productions like the Millennium saga: since the premiere of the films the Stockholm City Museum has hosted a "Millennium Tour," which was booked by 10,000 tourists in 2010. There were also tourists that took the tour on their own, since the Tourist Centre offered a map that featured several locations -the museum estimates that 25,000 people chose this option instead (Sparre \& Lind, 2011).

Focusing on TV series, there are also several cases that are drawing more and more tourists to the countries. Gustavssen from VisitDenmark states that "the number of nights spent by UK visitors in Denmark has soared in recent years. This is in part thanks to the huge success of Danish TV series Forbrydelsen (The Killing in the USA), Borgen and Bron/Broen (The Bridge in the USA)" (Beard, 2014).

Curiously enough, the tour around locations of these last three TV series is ranked number 8 out of 73 Outdoor Activities in Copenhagen (TripAdvisor United Kingdom Copenhagen, 2017). 
We could not put Game of Thrones in any of the above categories -it needed its own section. Contrary to an ordinary show, this one is shot in many different countries, including Northern Ireland, Croatia, Morocco, Iceland, Spain, or even Malta. That is the reason why we separated the show from the rest.

As the official web page of tourism in Northern Ireland states, "Game of Thrones is currently one of the most globally popular TV programmes in the world, watched by over 18.4 million viewers. With almost 20 million Facebook followers, over 4.7 million Twitter followers and 2.9 million Instagram followers, the popularity and success of the series is clear" (Tourism Northernireland, 2017). With this in mind, we cannot deny that those are more than reliable proof that Game of Thrones can attract on its own millions of people to all its filming locations.

Spain was chosen to represent the Kingdom of Dorne. It has only been seen in season 6 but there is already a growth in the number of visits to Andalusia, especially Cordoba and Seville. Just in 2015 tourism increased in the latter city up to $25 \%$ (Domínguez, 2015). Croatia is the famous capital of the Seven Kingdoms, Kings Landing, as well as Braavos and Meereen, practically all of them set in Dubrovnik. Since 2012 Dubrovnik and Split have seen the number of tourist rise -10 million tourists said Game of Thrones was their main reason to travel.

Iceland, on the other hand, has expanded up to $30 \%$ the visits in the last year, as it has been for the entire show The Wall and "the Lands beyond The Wall" (Jane, 2016). As Richard Williams said, "there are people in China who do not know where Northern Ireland is, but they know Titanic and they know Game of Thrones, and we need to capitalize on that" (Girvin, 2016). That is why Northern Ireland, representing Winterfell on the small screen, by funding $£ 13.75 \mathrm{~m}$, have received, in name of the show, a total (estimated) of $£ 150$ million (Jane, 2016).

\begin{tabular}{ccc}
\hline \multicolumn{2}{c}{ GAME OF THRONES ECONOMIC IMPACT IN NORTHERN IRELAND (GIRVIN, 2016) } \\
\hline $\begin{array}{c}\text { GAME OF THRONES } \\
\text { ECONOMIC IMPACT }\end{array}$ & $\begin{array}{c}\text { Funding from } \\
\text { Northern Ireland Screen }\end{array}$ & $\begin{array}{c}\text { Expenditure on goods and services } \\
\text { into the Northern Ireland economy }\end{array}$ \\
\hline Pilot / Series 1 & $£ 3.2 \mathrm{~m}$ & $£ 21.2 \mathrm{~m}$ \\
\hline Series 2 & $£ 2.85 \mathrm{~m}$ & $£ 21.8 \mathrm{~m}$ \\
\hline Series 3 & $£ 3.2 \mathrm{~m}$ & $£ 22.5 \mathrm{~m}$ \\
\hline Series 4 & $£ 1.6 \mathrm{~m}$ & $£ 23.2 \mathrm{~m}$ \\
\hline Series 5 & $£ 1.6 \mathrm{~m}$ & $£ 26.3 \mathrm{~m}$ (Estimated) \\
\hline Series 6 & $£ 1.3 \mathrm{~m}$ & $£ 31 \mathrm{~m}$ (Estimated) \\
\hline
\end{tabular}




\section{INTERNATIONAL TOURIST ARRIVALS}

IN CROATIA

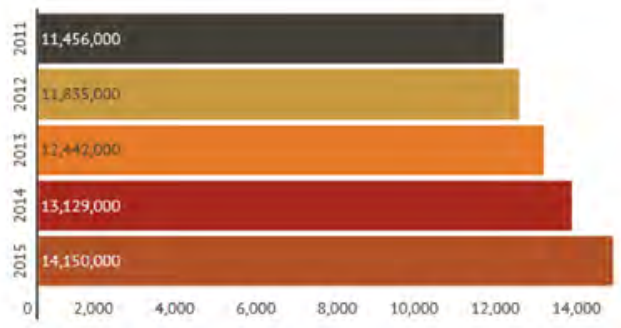

\section{INTERNATIONAL TOURIST ARRIVALS IN ICELAND}

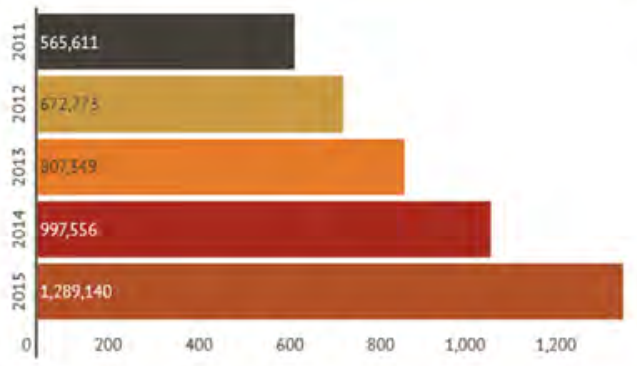

\section{INTERNATIONAL TOURIST ARRIVALS IN ANDALUCIA}

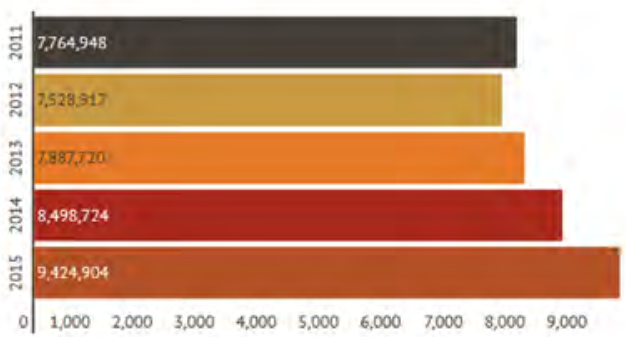

Tourist Arrivals in Croatia, Iceland and Andalusia (Jane, 2016). 
Both trilogies have undoubtedly changed New Zealand's image to the world, becoming a more interesting and attracting place to visit. It is not longer just the place where you take your vacation.

The manager of Western Long haul markets for Tourism New Zealand, Gregg Anderson, said:

We have seen a $50 \%$ increase in arrivals in New Zealand since Lord of the Rings: The fellowship of the Ring (2001, Peter Jackson). About $1 \%$ of visitors said that Lord of the Rings was the reason they came. It's only $1 \%$, but that's worth NZD \$33 million [currently US\$27 million] a year. Six percent cited Lord of the Rings as one of [emphasis mine] the major reasons they came. But the really important thing is that upwards of $80 \%$ of our target audience understands that The Lord of the Rings and The Hobbit has been filmed and is being filmed in New Zealand (Pinchefsky, 2012).

Matamata, the place where you can find the famous Hobbiton, Queenstown or even hills of Mount Victoria -all these are scenarios that have helped to develop the most iconic cinematographic Middle Earth, and all of them have experienced an increase in their visits. From the total of $\$ 11$.8billion spent by tourists, $18 \%$ belong to people whose initial interest is to enjoy a hobbit experience, and a total of $30 \%$ of visitors confirmed they consumed a Hobbit related experience.

In the table below, we can see how New Zealand, after the release of the first Lord of the Rings film, has seen a 10\% increase every year (from 1998 to 2003) from UK, although the most important tourism, as expected, comes from Australia.

\begin{tabular}{|c|c|c|}
\hline \multicolumn{3}{|c|}{ FILM TOURISM IMPACTS (HUDSON \& RITCHIE, 2006) } \\
\hline FILM OR TV SERIES & LOCATION & $\begin{array}{c}\text { IMPACt ON VistToR NumBers OR TOURIST REvE- } \\
\text { NUE }\end{array}$ \\
\hline Braveheart & Wallace Monument, Scotland & $300 \%$ increase in visitors year after release \\
\hline Heartbeat & $\begin{array}{l}\text { Goathland. North Yorkshire. } \\
\text { England }\end{array}$ & $\begin{array}{l}\text { Three times the number of normal visitors } \\
\text { in } 1991\end{array}$ \\
\hline Deliverance & Rayburn County. Georgia & $\begin{array}{l}20000 \text { film tourists a year Gross revenues } \$ 2 \\
\text { to } 3 \mathrm{~m}\end{array}$ \\
\hline Dances with Wolves & Fort Hayes. Kansas & $\begin{array}{l}25 \% \text { increase compared with } 7 \% \text { for previous } \\
4 \text { years }\end{array}$ \\
\hline $\begin{array}{l}\text { Close Encounters of the } \\
\text { Third Kind }\end{array}$ & Devils Tower, Wyoming & $\begin{array}{l}75 \% \text { increase in } 197520 \% \text { visit now because } \\
\text { of the film }\end{array}$ \\
\hline Thelma and Louise & $\begin{array}{l}\text { Arches National Monument in } \\
\text { Moab. Utah }\end{array}$ & $19.1 \%$ increase in 1991 \\
\hline Field of Dreams & Iowa & 35000 visits in 1991 Steady increase every year \\
\hline Dallas & Southtork Ranch. Dallas & 500000 visitors per year \\
\hline The Lord of the Rings & New Zealand & $10 \%$ increase every year 1998 to 2003 from UK \\
\hline
\end{tabular}




\begin{tabular}{|c|c|c|}
\hline Steel Magnolias & Louisiana & $48 \%$ increase year after release \\
\hline Last of the Mohicans & $\begin{array}{l}\text { Chimney Rock Park, North } \\
\text { Carolina }\end{array}$ & $25 \%$ increase year after release \\
\hline The Fugitive & Dillsboro. North Carolina & $11 \%$ increase year after release \\
\hline Little Women & $\begin{array}{l}\text { Orchard House. Concord. } \\
\text { Massachusetts }\end{array}$ & $65 \%$ increase year after release \\
\hline Bull Durham & Durham. North Carolina & $25 \%$ increase in attendance year after release \\
\hline Harry Potter & Various locations in UK & All locations saw an increase of $50 \%$ or more \\
\hline Mission: Impossible 2 & National parks in Sydney & $200 \%$ increase in 2000 \\
\hline Gorillas In the Mist & Rwanda & $20 \%$ increase in 1998 \\
\hline Crocodile Dundee & Australia & $20.5 \%$ increase in U.S. visitors 1981 to 1988 \\
\hline The Beach & Thailand & $22 \%$ increase in youth market in 2000 \\
\hline $\begin{array}{l}\text { All Creatures Great } \\
\text { and Small }\end{array}$ & Yorkshire Dales & Generated $£ 5 \mathrm{~m}$ for Yorkshire Dales \\
\hline To the Manor Born & $\begin{array}{l}\text { Cricket St Thomas, Leisure Park. } \\
\text { England }\end{array}$ & $37 \%$ increase between 1978 to 1980 \\
\hline Middlemarch & Stamford, Lincolnshire, England & $27 \%$ increase in 1994 \\
\hline $\begin{array}{l}\text { Four Weddings and } \\
\text { a Funeral }\end{array}$ & $\begin{array}{l}\text { The Crown Hotel. Amersham. } \\
\text { England }\end{array}$ & Fully booked for at least 3 years \\
\hline Mrs. Brown & $\begin{array}{l}\text { Osborne House. Isle of Wight, } \\
\text { UK }\end{array}$ & $25 \%$ increase \\
\hline Notting Hill & Kenwood House, England & $10 \%$ increase in 1 month \\
\hline Saving Private Ryan & Normandy. France & $40 \%$ increase in American tourists \\
\hline Sense and Sensibility & Saltram House, England & $39 \%$ increase \\
\hline Pride and Prejudice & Lyme Park in Cheshire, UK & $150 \%$ increase in visitors \\
\hline Cheers & Location in Boston & $\begin{array}{l}\$ 7 \mathrm{~m} \text { in unpaid promotional advertising each } \\
\text { year }\end{array}$ \\
\hline Miami Vice & Miami & $\begin{array}{l}150 \% \text { increase in German visitors } 1985 \text { to } \\
1988\end{array}$ \\
\hline Forrest Gump & Savannah, Georgia & $7 \%$ increase in tourism \\
\hline Troy & Canakkale, Turkey & $73 \%$ increase in tourism \\
\hline $\begin{array}{l}\text { Captain Corelli's } \\
\text { Mandolin }\end{array}$ & Cephalonia. Greece & $50 \%$ increase over 3 years \\
\hline
\end{tabular}

\section{CINEMA AS A MARKETING TOOL}

The same as many important brands use smells or colors for people to associate them with their products (The Independent, 2011), governments are realizing that actors and landscapes can play the exact same role when promoting a destination 
-people could relate movies to the cities or countries where they were filmed, and that could lead to an increase in the number of tourists, as we have explained before.

"Destinations and experiences are enhanced in audiences' memories by special technological effects, association with famous actors, and the cinematic penchant for picture perfect settings" (Riley \& Van Doren, 1992: 269). It is usual to find locations that carried no meaning by themselves: they were not important before hosting a movie shooting and they were not visited by tourists or people in general as a consequence of that, but even so they can become relevant after providing with value the places affecting the memories of a person. Such is the case of the island of Khao Phing Kan in Thailand, currently also known by the name of James Bond Island.

That said, there are several accepted methods related to film-induced tourism that are being applied to boost tourist arrivals in a place. The more traditional guided film tours and walks are now joined by other strategies, one of the most effective being the collaborative campaigns between DMOs (Destination Management Organizations) and the film industry:

DMOs are beginning to forge relationships and provide incentives for film commissions to track productions and film releases so the organizations can act as soon as they see the signs of a film. Various DMOs are trying to entice producers to make films in their countries since it clearly shows that the economic impact is immense (Rewtrakunphaiboon, 2009: 6).

After reading some articles regarding this topic, there are authors that accentuate the following idea: what if the attributes of a place were treated as a traditional product featured in a scene? -Business Dictionary defines product placement as "an advertising technique used by companies to subtly promote their products through a non-traditional advertising technique, usually through appearances in film, television or other media."

It is not difficult to find examples of this strategy in entertainment media: to name but a few, Pepsi and Nike in Back to the Future, Manolo Blahnik in Sex and the City, Kodak Carousel in Mad Men..., without forgetting Apple products: according to The Verge, the firm had the most product placement in the films of 2014 (Yoshida, 2015).

Nevertheless, effective as it is, some experts agree that it may well be being overused-since this marketing method can be seen as aggressive and many people could end fed up with it, it surely is a better idea to promote a city, a hotel, a restaurant... in a more subtle way. "Promotion of hotels, guesthouses and dining places featured in the film can be a powerful magnet to generate tourism" (Rewtrakunphaiboon, 2009: 7). There are some examples for this, as well: The Crown Hotel at Amersham (England) promoted the room that Hugh Grant used in Four Weddings and a Funeral, and it was fully booked for at least three years after the release of the film. In Cephalonia (Greece) a lodge was advertised as the location of the alleged affair between Nicholas Cage and Penelope Cruz in Captain Corelli's Mandolin (Hudson \& Ritchie, 2006b: 256-258). 
As Morgan and Pritchard say in the book Tourism Promotion and Power: Creating Images, Creating Identities (1998), placing a destination in a film is the ultimate in tourist product placement. So, just as product placement can influence the viewer's attitude towards a brand, films can also have a huge impact on the image of a place.

El cine... juega un papel importantísimo en la creación de la imagen de un destino, un territorio, una ciudad o un país como posible destino turístico. Sus mensajes no se perciben como publicitarios, ya que la mente del receptor está abierta a la recepción tanto en dimensión subconsciente como consciente (a diferencia de un mensaje percibido como publicitario), por lo tanto los efectos persuasores se hacen mayores.

What Konstantin Stanishevski (2007: 261-264) points out above is that cinema itself plays an important part in the creation of the image of a territory, a city, or even a country that has possibilities of becoming a tourist destination. When messages are not perceived as advertising, the receptor's mind is open to a subconscious and conscious dimension and the persuasive effects are bigger.

One of the main differences between product placement and other strategies is the significance of the factors contributing to it, such as context and environment (John Dudovskiy, 2012).

Consequently, as brands need to be careful about every aspect that surrounds the product being placed, the same should be made when placing a destination. Whereas many can think this is an easy-to-deploy tactic, there are important elements that need to be taken into account (Fan Yang, 2001: 25). First of all, the scriptwriters need to care about the message (story), and the key factor would be to include the place into this storyline, so it increases people's interest. But, as the author added to the article, there are other elements that are as important as this one: the characters, the emotions and the logic/reasoning (Tooke \& Baker, 1996: 87-94).

Iwashita (2008: 141) also supports this idea: "the locations associated with exciting sequences, story-line themes, symbolic contents, favorite performers and human relationships become special places for viewers (...)"

Additionally, as brands need to differentiate themselves and their products from its competitors, countries and cities should do the same in order to attract more people. Quoting Fan Yang (2011: 2), "the biggest challenge for marketers in the field of destination branding is how to build emotional ties between visitors and locations."

As Fan Yang also says, in turn, when branding a place, other authors -Florek, Insch \& Gnoth (2006: 276-296)- have explained that the subjects can be seen as mega-products. Due to this fact, it is also believed that these said places can satisfy functional, symbolic and emotional needs, just like general product brands do.

In destination branding the importance of film-induced tourism has escalated quickly in the past few years -in the end, as published in Proceedings of The 7th MAC 2016 (2016: 3), "people tend to visit particular places by specific images, memories, associations and emotional attachments to places and meanings" (Schama, 1996). 
Has your organization ever implemented one of the following promotional tools when dealing with film tourism?

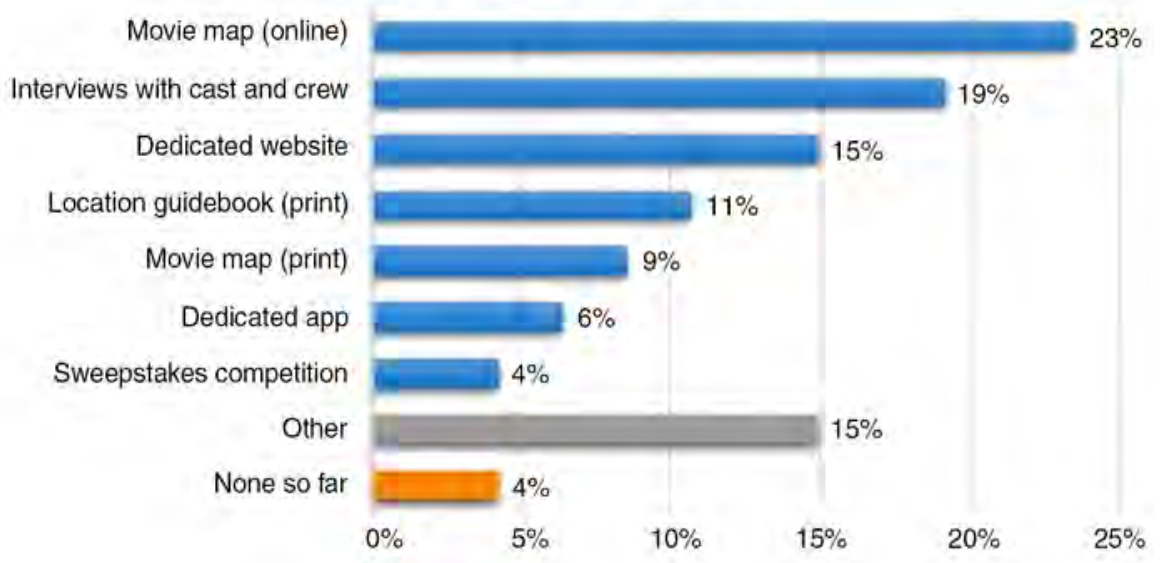

Tools to implement Film Tourism (Roesch, 2016: 1).

Needless to say, should governments want to implement this method of promotion, it would need to be enforced properly. As previously pointed out, product placement can have an adverse impact on a brand, and it can also go wrong for a destination if it is portrayed in a negative way.

\subsection{InTERnet INFLuences}

Apart from the traditional methods and branding places, we can't miss out on the internet. While searching surveys for our work, we found lots of websites that are very effective when it comes to promote a destination -the internet offers so many useful tools that it is being used more and more by organizations and film commissioners, as we can see in the graphic below:

As a freshness, we should highlight the phone apps, which are becoming more popular among fans and tourists - they are cheap (most of them are free, even) and they are available anytime you need them. One of the most famous is Movieloci: it offers an interactive map with over 600 exact locations of more than 150 movies all around the world and a list of films near the current location of the user.

There are also collaborative websites where fans are able to submit and add locations all around the world, such as The Movie Map. Another one that actually helped us while writing our work is Movie-Locations.com -here you can find a global map, and when clicking on one specific country, you can see a list of movies that were filmed there.

On the other hand, and as we already know, there are a lot of people (in this case, tourists) that follow the trends in order to feel socially accepted, due to the fact 
that we need to feel that we belong somewhere. This explains the increase of blogs and internet sites dedicated to film-induced tourism. One of the most famous and relevant is Fanguirlquest: the owners travel around the world visiting movie locations and post pictures on their blog or social networks - their Instagram account has currently around $23.4 \mathrm{k}$ followers.

\section{SPAIN AND THE CANARIES}

When it comes to Spain, "the reason why foreign cinema was the almost exclusive creator of the outer image of Spain should be looked for in the fact that, until the last decades, the works of the Spanish film directors, with the exception of Luis Buñuel, almost never crossed national borders, because of the international isolation due to the dictatorial regime of general Franco, together with the censorship imposed by him and the weak Spanish cinematographic industry" (Mestre y Del Rey, 2010).

Nevertheless, thanks to the exhibitions in cinematographic festivals, international Spanish film directors like Pedro Almodóvar or Alejandro Amenábar have had the possibility to change progressively Spain's image and, as a consequence, they are making it more appealing for everyone, including film production companies.

The leading area in Spain to host international companies and use their landscape as a promotional tool has been Andalusia, with movies like Alatriste (Agustín Díaz Yanes, 2006) or Lawrence of Arabia (David Lean, 1962), but this keeps growing constantly. Almeria particularly is known for hosting Spaghetti Westerns, also known as European Westerns, which took recognition thanks to Sergio Leone, the main director on the field. Most of the locations were set in Cinecittá (Italy) and Spain, with movies like Il buono, il brutto, il cattivo (Sergio Leone, 1966). Curiously, there is a theme park called Western Leone were you can feel as you belong to a western movie like Once Upon a Time in the West (1968, Sergio Leone), or For a Fistful Dollars (Sergio Leone, 1964).

Orson Welles, the famous American director, actor and writer, also known by many as Rita Hayworth's husband, was passionate about Spain. Along with Ernest Hemingway, he became involved in the defense of the Spanish legacy, which he tried to preserve and promote. This ended up being a reason why he filmed many of his movies in the country. Mr. Arkadin (1955), Histoire Immortelle (1968), Fraude, F For Fake (1973) or Falstaff-Chimes at Midnight (1965) are examples of his work in Spain, causing today the creation of specific routes along the country just to visit Welles scenarios.

Focusing on the Canary Islands, specifically on Tenerife, we have found that the record of productions hosted was beaten last year, with a total of 116 (Tenerife bate en..., 2017). There are several movies that have helped Tenerife to get to this point: Clash of the Titans (Louis Leterrier, 2010) and One hour more in the Canary Islands (Una hora más en Canarias, David Serrano 2010). These two productions managed to allure new film production companies like Original Film and One Race Film (thanks to Universal Studios), without forgetting the shooting of Fast 
and Furious 6 (Justin Lin, 2013). But let's not think this is something totally new, remember films like Moby Dick (John Huston, 1956) or When Dinosaurs ruled the Earth (Val Guest, 1970) -the first one was shot in Gran Canaria and the second in Fuerteventura.

Here in the Islands it all began using product placement in the form of ads, like the one in the Red Square in Moscow that quoted "Canary Islands, warm nature," or on the Great Wall of China with the title "The Canary Islands greet China." We were projecting our paradise as a "miniature continent" with infinite possibilities. Eventually, this is what has led to the creation of Film Commissions, emerged to attract filming companies and to create wealth in geographic areas that could become suitable locations, either to shoot entirely or only parts of a film or television series. These film commissions facilitate all permissions required and put producers in touch with local companies that could participate in the shooting.

In addition, the same as gay-friendly or pet-friendly hotels are conceived, a completely new concept has seen the light: film-friendly hotels are designed to be adapted in terms of schedule, spaces, meals, equipments... to the film production companies.

Tenerife was the first island to create its Film Commission and the first one to join the Spain Film Commission, an institution in charge of the national and international promotion of the archipelago as a cinematographic set. Gran Canaria followed suit, as "people could be travelling around the world by only visiting the seven islands." Then came La Palma and lastly La Gomera, but this one is still just a project. It comes as a surprise that El Hierro and Fuerteventura have not worked towards the creation of their own Film Commission, despite the fact of having $E x$ odus: Gods and Kings (2014, Ridley Scott) filmed in Fuerteventura, which opened the doors of the island to the world. Lanzarote, on the other hand, does have its own Film Commission, as Timanfaya National Park is the most required scenery (Sola, 2015: 588-602).

\subsection{Tenerife}

Nowadays, the model of tourism implanted in the Canaries establishes a clear relationship between the strategic plans of local development and the power of the mass media, in order to improve a territories image as a possible tourist and film destination.

The main proposal is to create a participatory system that increases the benefits, in medium and long term, for the insular Tax office, the professionals in the sector, companies, and individuals willing to invest in the management model.

This would allow the creation of an Audiovisual Industry in the archipelago. The last action of the sector has been the creation of the "Cluster Audiovisual de Canarias" (CLAC), which intends to manage the process and tries to affiliate those that are interested in the industry, acting as an intermediary.

On their website you can find specified all the actions they are carrying out, as well as future plans: 
1. Coordinate the private investment of the Canary Islands in the Film Industry.

2. Create an international venture capital fund to invest in the Canaries audiovisual industry.

3. Make the process known to partners.

4. Be the interlocutor between the sector, the government, and the different institutional organisms.

5. Trade internationally audiovisual products from the Canary Islands.

6. Provide specialized training in the Archipelago.

7. Create alliances with other Spanish and European Clusters (Clúster Audiovisual..., 2015).

With all of this, the CLAC wants to transform the Canary Islands in the perfect place to shoot movies due to its special taxation, the endless investment possibilities, its climate and landscape and also their infrastructures. The main objective is to develop and professionalize the audiovisual sector in the Islands, and attain a competitive position in the new commercial and international scene.

Furthermore, the CLAC offers a series of advantages that would be obtained when being part of the Cluster. They go as follows:

1 Collectively provide resources to compete and lead the sector.

2. Monitoring the evolution of the film industry in the islands through the associated companies.

3. Create partnerships to improve productivity when it comes to supplies and sales.

4. To gain visibility and power in front of the Government Institutions.

5. Lastly, to be able to create a quality brand that relates the Canary Islands to the film industry.

Obviously, getting back to Tenerife's case, the audiovisual use of the island does not have the same repercussion as filming in a big city (New York, London, Paris...), but it does not want to fall into a senseless use of our landscape without control or a cultural feedback that reinforces the economic one.

As we said earlier, Turismo de Tenerife has developed two tourist routes regarding the first important films shot in the island: Clash of Titans and One More Hour in the Canary Islands. By entering the official webpage you can find all the information related to both routes:

- Shooting locations.

- Where to take photos.

- Where to eat.

- Anecdotes about the shootings.

In short, a whole series of data to relive the feelings experienced when watching the film, and to enjoy a parallel experience for a new kind of cultural and film-interested tourist. Obviously, this phenomenon is totally new in the archipelago, but you still can find a link to a KMZ file with all the locations on an 
interactive map of the island. This is the so-called Moviemap: a theme route map with indications of each location or scenery shown in a film.

All in all, marketing strategies play a key role in this new kind of tourism, as an important reflection of the success of a movie.

\section{DISCUSSION AND RECOMMENDATIONS}

Taking into account the aspects explained above, now it is time to analyze the work that has been performed in Tenerife and in the Canaries so far. Later on, we will point out our recommendations or ideas to try and make of this plan a solid strategy in the future.

As we read in lots of articles that talk about the amount of shootings that have been taking place in the islands, we cannot deny the impact that they have on our economy: according to the local government, just in the last five years the shootings hosted in the Canaries provided an investment of $€ 130$ million (Quintero, 2016).

Zooming in on Tenerife, and as mentioned before, the island broke its record of shootings, making a $€ 6,5$ million profit from them (Tenerife bate..., 2017). But it is not enough just to allure film companies to shoot here. In the end, money just comes and goes. That is why we need to implement a whole system that supports this project.

As Donata Juškelyte explains in her article Film Induced Tourism: Destination Image Formation and Development (2016: 60), the impact that many films have in many countries is related to the industry built around them (theme parks, merchandise, events...), and also due to the actions carried out in these three stages -pre-production, production and post-production.

That is also why tourism can be so important and play a key role: as we pointed out before, it can give meaning to a place, managing to attract more and more people consistently. Furthermore, among other things, it creates jobs for locals (instead of the ones offered by the film companies, which are often aimed at foreigners). A great example could be the shooting of Game of Thrones, which created approximately 900 full-time and 5700 part-time jobs for locals in Northern Ireland (Burns, 2016).

Starting to name our recommendations, first of all, we would make sure that tourists are actually willing to take part in the movie walks or in any other activity related to cinematographic productions. If they are not enthusiastic about it, it would not make sense at all to keep going with this. So, for example, it would be really useful to know how many people are already going to the routes created in Tenerife-the ones organized around locations featured in Clash of the Titans and Una hora más en Canarias. This could also be done by taking surveys that help find out the commitment of the tourists regarding this new kind of tourism, since maybe they are not interested in those movies, yet they could be keen on others.

We also looked into some of the newest types of tourism in Tenerife, just to compare them with what could be done with film-induced tourism: those are astronomical tourism and sport tourism. Both are relatively new and we did not 
find much information about them, but with the help of Promotur we discovered important and interesting facts that were worth the analysis.

Regarding astronomical tourism, we can say that it is definitely still growing: according to María Méndez, the managing director of Promotur, only in 2015 Tenerife received 200000 tourists that climbed El Teide only to stargaze, without necessarily being experts in the field (Canarias apuesta..., 2015).

Due to the geographic location of the islands and the Starlight certifications of La Palma, Tenerife and Gran Canaria, the Canaries are now being considered as a relevant astronomic destination. Looking at the actions implemented to help astronomical tourism's growth, we can highlight a few focusing on Tenerife:

- The Volcano Life Experience: it offers a wide range of activities in Teide National Park.

- Discover Experience Tenerife: they not only organize activities related to stargazing, but also help spreading the knowledge and importance of astronomy and a healthy environment within locals.

- Other private companies such as Dixkover.

In the case of sport tourism, we did find more information.

According to the Marketing Plan of the Canaries in 2016, active tourism involves all kinds of water sports, nature sports, golf, sailing and diving.

Bearing this idea in mind, we found a chart that shows the evolution (from 2011 to 2015) of the factor "active tourism" when it comes to the following question: Why have you chosen to travel to the Canaries?

\begin{tabular}{|c|c|c|c|c|c|}
\hline \multicolumn{6}{|c|}{ PROMOTUR (EVOLUCIÓN DEL PERFIL..., 2015) } \\
\hline \multicolumn{6}{|l|}{ ¿POR QUÉ ELIGEN CANARIAS? } \\
\hline Aspectos que influyen en la elección & 2011 & 2012 & 2013 & 2014 & 2015 \\
\hline Clima/Sol & $90,2 \%$ & $90,9 \%$ & $90,0 \%$ & $90,1 \%$ & $89,3 \%$ \\
\hline Tranquidad/descanso/relax & $41,5 \%$ & $41,1 \%$ & $39,0 \%$ & $39,0 \%$ & $37,9 \%$ \\
\hline Playas & $33,6 \%$ & $33,7 \%$ & $34,1 \%$ & $34,3 \%$ & $33,6 \%$ \\
\hline Paisajes & $21,6 \%$ & $20,1 \%$ & $20,4 \%$ & $21,3 \%$ & $22,6 \%$ \\
\hline Precio & $15,2 \%$ & $15,3 \%$ & $14,3 \%$ & $15,1 \%$ & $14,1 \%$ \\
\hline Conocer nuevos lugares & $14,9 \%$ & $15,0 \%$ & $14,1 \%$ & $14.4 \%$ & $14,1 \%$ \\
\hline Facilidades de traslado & $9,1 \%$ & $9,1 \%$ & $8,7 \%$ & $8,4 \%$ & $8,3 \%$ \\
\hline Un lugar adecuado para nińos & $7,8 \%$ & $7,8 \%$ & $8,0 \%$ & $8,6 \%$ & $7,7 \%$ \\
\hline Calidad del entorno ambiental & $6,5 \%$ & $6,1 \%$ & $6,5 \%$ & $6,0 \%$ & $6,4 \%$ \\
\hline Seguridad & $5,6 \%$ & $5,0 \%$ & $5,2 \%$ & $5,1 \%$ & $7,5 \%$ \\
\hline Ambiente nocturno/diversión & $5,2 \%$ & $5,4 \%$ & $5,1 \%$ & $4,4 \%$ & $4,3 \%$ \\
\hline Oferta de turismo activo & $3,9 \%$ & $4,2 \%$ & $4,7 \%$ & $4,9 \%$ & $5,2 \%$ \\
\hline
\end{tabular}




\begin{tabular}{llllll}
\hline Compras & $3,2 \%$ & $3,2 \%$ & $2,8 \%$ & $3,0 \%$ & $3,0 \%$ \\
\hline Parques de ocio & $2,5 \%$ & $2,7 \%$ & $2,6 \%$ & $2,7 \%$ & $3,1 \%$ \\
\hline Oferta cultural & $2,4 \%$ & $2,4 \%$ & $2,6 \%$ & $2,5 \%$ & $2,7 \%$ \\
\hline Actividades Náuticas & $2,0 \%$ & $2,0 \%$ & $2,3 \%$ & $2,3 \%$ & $2,1 \%$ \\
\hline
\end{tabular}

* Pregunta multírrespuesta.

Looking at the table we can see that, along the years, this option has gained popularity when it comes to deciding whether or not to come to the Canaries.

After realizing the importance and impact that this kind of tourism can have on the islands, the government has been implementing many actions to boost it. Just to name a few examples:

1. Training Non Stop: This website includes everything related to the practice of sports in the islands (what sports can be practised, locations, news...)

2. The Canary Way of Surf: This web is a great help for people that want to practice water sports, and the same goes for the app called "Water Sports Experience."

3. The Transvulcania Ultramarathon: It is one of the biggest sport events in the Canaries and it hosts more participants every year, not only athletes but also the media.

Following these steps, we find that something similar could be done regarding film-induced tourism -once we know there are people interested in it, it is important to create platforms and websites to boost it.

Not all countries are aware of the benefits that hosting a television or film production can bring, and most of them do not work towards the improvement of their online promoting system. For instance, England and New Zealand, two great well-known countries, have a specific area on their official tourist websites dedicated to television and cinema. On the contrary, Croatia or Morocco, both locations used in George R.R. Martin creation Game of Thrones, do not mention anything on their webs, despite the special tours offered outside them.

Regarding the Canary Islands, we know that the government is currently promoting the archipelago as a television set, as there is a website promoting the benefits and privileged characteristics of the islands, but these campaigns are mostly targeted at investors, not at tourists. That is why we say that it is important to take everything into account, turning this strategy into a whole integrated system.

However, we do know that, at least for now, we should treat movie-induced tourism as a complementary good.

\subsection{Proposals For FURTHer aCtions}

After all the facts displayed above, we present now our suggestions to make a more successful approach to this new kind of tourism. 
First of all, we consider that it would be better to inform tourists once they are here, instead of giving much information away in origin countries -this is new for most people, so it would not make sense to promote it as a big or established phenomenon. But to make specific arrangements with hotels, malls, to put banners in strategic locations (main highways of the island, airports...) could favorably lead to an increase of attention and curiosity.

Our next idea is related to the countless advantages that the internet provides. As we said in the last section, a great project would be to design a web aimed at tourists and not only at investors. To an extent, it is useful to know all about the tax incentives and grants that we offer, but being honest, tourists do not care about that. Therefore, we think it can be great to create a site that contains all the information regarding locations, visits, recommendations, itineraries ideas...

Another good addition to this would be to engage famous actors that came to the islands in the promotion, perhaps through online campaigns, since they are cheaper and could reach more people. There are countries that have been doing this for some time, one of the most popular examples is the campaign carried out by Air New Zealand, in which they explain the flight safety procedures using The Hobbit actors (The Most Epic..., 2014).

Focusing on international tourism, it is essential to be present in the most famous and important International Tourism Trade Fairs, such as FITUR or ITB Berlin. We are aware that the Canary Islands are promoting themselves abroad (Canarias unifica..., 2016), but once again, all of these actions are addressed to investors and film companies.

At present, we are living in a moment that is clearly positive for the Canaries -all competitors, such as Tunisia, Turkey, or Egypt, are going through rough times due to several reasons (terrorism, insecurity, political instability...). As data reflect (Canarias eleva..., 2017), the Islands received 13297883 tourists in 2016, 13,2\% more than the previous year, hence the opportunity of not letting this moment pass by without taking advantage of it.

\section{CONCLUSIONS}

Film-induced tourism is a phenomenon that emerged many years ago, and it is a tool that has been used by several countries, consciously or not. Historically, there are countries (such as the United States or the United Kingdom) that are much more experienced in this field, since they have a larger film industry.

Recently, and due to the success of productions like Harry Potter or The Lord of the Rings, more and more governments are being aware of the benefits that come with promoting a destination through cinema or TV: one of the clearer examples is the case of Northern Ireland and Game of Thrones.

Regarding Spain, there are also areas of the country, such as Almeria, that are much more competent than others -they have been hosting productions for a longer period of time. However, new autonomous regions are emerging for different reasons, the Canaries being one of them. 
In the case of the Islands it all started a few years back: we reached a turning point in 2010 with Clash of the Titans, and it kept growing from there, reaching the number of 116 productions in 2016.

In terms of the future, new measures taken by the Spanish government have recently come to light. Among them, we can highlight the increase in the tax deductions on national projects (from $35 \%$ to $48 \%$ on the first invested million and $40 \%$ on the rest) as well as on international productions (from $35 \%$ of the total expenditure to 40\%) (El Clúster celebra... 2017).

We really think that the Canaries have a brilliant opportunity to become an important place for shootings within Spain, not only because of the economic part, but also because of our landscape, geographical situation, infrastructures... so we hope that this situation does not become a passing fad and that the government keeps working towards this project. 


\section{SOURCES}

BIBLIOGRAPHY (BOOKS AND JOURNALS)

Akbulut, O., Ekin, Y. \& Celik Yetim, A. (2016): Residents' attitudes toward screen tourism: a case study of Bozuyuk, Mugla-Turkey. Proceedings of the Multidisciplinary Academic Conference.1-8. Basken University Library. Retrieved from: http://katalog.baskent.edu.tr/client/ en_US/default/search/federateddetailnonmodal/\$N/EDS/a9h\$007c\$007c115706660;jsessionid=CE59235A9EA9F52DDA2B682D472875CF?qu=Cities+and+towns+--+Turkey+--+Social+conditions.\&rw=2\&ic=true\&ri=ele6fee5-65b2-4f35-88a7-0aaca2f1ad1a. rbMMG6F1oxGCNKrX8GMpcZZVc4Yp7bup1HOI848ONdY\%3D\&te=1083500324 \&lm=ALL\&ps=300 (Accessed: March 27, 2017)

BAKкeR, G. (2008): The Economic History of the International Film Industry. EH.Net Encyclopedia. University of Arizona. Retrieved from: http://eh.net/encyclopedia/the-economic-history-of-the-international-film-industry/ (Accessed: March 4, 2017).

Croy, W.G. \& Walker, R.D. (2003): Rural tourism and film: Issues for strategic regional development. In D. Hall, L. Roberts \& M. Mitchell (eds.), New directions in rural tourism (pp. 115-133). Aldershot: Ashgate.

Connell, J. (2012): Tourism Management. Film tourism-Evolution, progress and prospects, 33(5), 1007-1029. Retrieved from: http://www.sciencedirect.com.accedys2.bbtk.ull.es/science/ article/pii/S0261517712000404 (Accessed: February 25, 2017).

FloreK, M. Insch, A. \& GNOTh, J. (2006): City council websites as means of place brand identity communication. Place Branding, 2(4), 276-296.

Grinault, N. (2003): Film Tourism: The Global Picture. Travel \& Tourism Analyst, 5, 1-22.

Hoffmann, Nicole B. (2015): On-location film-induced tourism: success and sustainability (Masters dissertation). University of Pretoria, Pretoria. Retrieved from http://repository.up.ac.za/ handle/2263/50623 (Accessed: February 25, 2017).

Hudson, S. \& Ritchie, J.R.B. (2006a): Promoting destination via film tourism: An empirical identification of supporting marketing initiatives. Journal of Travel Research, 44(4), 387-396. Retrieved from: http://www.academia.edu/3432925/Promoting_destinations_via_film_ tourism_an_empirical_identification_of_supporting_marketing_initiatives (Accessed: February 20, 2017)

Hudson, S. \& Ritchie, J.R.B. (2006b): Film tourism and destination marketing: The case of Captain Corelli's Mandolin. Journal of Vacation Marketing, 12(3), 256-268.

Iwashita, C. (2008): Roles of Films and Television Dramas in International Tourism: The Case of Japanese Tourists to the UK, Journal of Travel \& Tourism Marketing, 24(2-3), 139-151.

JušKelytĖ, D. (2016): Film induced tourism: destination image formation and development. Regional formation and development studies, 2(19), 54-67.

Morgan, N. \& Pritchard, A. (1998): Tourism promotion and power: Creating images, creating Identities. Chichester: John Wiley \& Sons.

Perdue, R.R. \& Crouch, G.I. (ed.), Trimmermans, H.J.P., Uysal, M. (2004): Consumer psychology of tourism, hospitality and leisure. Wallingford: CABI. 
Petrea, R., Petrea, D., Olău, P., \& Filimon, L. (2013): Place Branding as Efficient Management Tool for Local Government. Transylvanian Review Of Administrative Sciences, 9(SI), 124140. Retrieved from http://rtsa.ro/tras/index.php/tras/article/view/402 (Accessed: March 19, 2017).

Poсоск, D. (1992): Geography. Catherine Cookson Country: Tourist Expectation and Experience, 77(3), 236-243.

Rey Reguillo. A. del (ed.) (2007): Cine, imaginario y turismos: estrategias de seducción. Valencia: Prosopopeya, Tirant lo Blanc.

Rewtrakunphaiboon, W. (2009): Film-Induced Tourism: Inventing a Vacation to a Location. $B U$ Academic Review 8, 33-42.

RILEY, R. \& VAN DoRen, C.S. (1992): Movies as tourism promotion: A pull factor in a push location. Tourism Management, 13(3), 267-274.

Rodríguez Hernández, P. (2015): El cielo de Canarias: observación y divulgación de la astronomía (Degree Final Dissertation). University of La Laguna, La Laguna. Retrieved from: https:// riull.ull.es/xmlui/bitstream/handle/915/1055/El\%20cielo\%20de\%20Canarias\%20observacion $\% 20 \mathrm{y} \% 20 \mathrm{divulgacion} \% 20 \mathrm{de} \% 20 \mathrm{l} \% 20$ astronomia.pdf?sequence $=1$ (Accessed: May 20, 2017).

Sharpley, R. \& Telfer, D. (2002): Tourist and Development: Concept and Issues. Clevedon/ Buffalo/Toronto: Channel View Publications. Retrieved from: https://books.google.es/ books?id=2idMK6rJnrcC\&pg=PT150\&lpg=PT150\&dq=literature+tourism+escape+reality\&source=bl\&ots=rDNC83BFsW\&sig=XzUfGAJFiOSt3eLGT-meY4KT6WQ\&hl=es\&sa=X\&ved=0ahUKEwj7oankvL_SAhXDL8AKHcFvD9kQ6AEIRjAF\#v=onepage\&q=literature\%20tourism\%20escape\%20reality\&f=false (Accessed: February 20, 2017).

Stanishevski, K. (2007): La comunicación de los destinos turísticos. In Rey Reguillo. A. del (ed.) Cine, imaginario y turismos: estrategias de seducción. Valencia: Prosopopeya, Tirant lo Blanc.

Tooke, N. \& Baker, M. (1996): Seeing is believing: The effect of film on visitor numbers to screened locations. Tourism Management, 17(2), 87-94.

\section{Thesis}

Sola Antequera, D. (2015): Como el ojo en el corazón del poeta. El fenómeno cinematográfio en Canarias en el último cuarto del siglo XX (1975-1998). (PhD thesis). Universidad de La Laguna, Tenerife.

YANG, F. (2011): Movies' impact on place images and visitation interest: a product placement perspective. (PhD thesis). Michigan State University, Michigan. Retrieved from: https://scholar.google. es/scholar?cluster $=5071436265730348953 \& \mathrm{hl}=\mathrm{es} \&$ as_sdt=0,5\&sciodt $=0,5$ (Accessed: March 25, 2017).

\section{Press}

Burns, A. (November 27, 2016): How 'Game of Thrones' brought Jobs and PR rebrand to Northern Ireland. The Big Issue. Retrieved from: http://www.bigissue.com/culture/game-thronesbrought-jobs-pr-rebrand-northern-ireland/ (Accessed: May 20, 2017). 
Canarias apuesta por las estrellas para enriquecer su oferta turística (September 27, 2015): Diario de Avisos. Retrieved from http://www.diariodeavisos.com/2015/09/canarias-apuesta-por-estrellas-para-enriquecer-su-oferta-turistica/ (Accessed: May 20, 2017).

Canarias eleva su Cifra récord de turistas extranjeros de 2016 a 13297883 (January 31, 2017): La Vanguardia. Retrieved from: http://www.lavanguardia.com/politica/20170131/413868131096/canarias-eleva-su-cifra-record-de-turistas-extranjeros-de-2016-a-13297883.html (Accessed: May 26, 2017).

Davies, L. (December 16, 2011): The Killing helps boost UK travel to Denmark. The Guardian. Retrieved from: https://www.theguardian.com/travel/2011/dec/16/the-killing-uk-traveldenmark (Accessed: March 16, 2017).

DeAn, J. (August 19, 2015): Goonies 'truffle-shuffle' house closed after owner gets fed up of 1,500 fans visiting every day. Daily Record. Retrieved from http://www.dailyrecord.co.uk/lifestyle/property/goonies-truffle-shuffle-house-closed-6282104 (Accessed: March 5, 2017).

Deviln, V. (August 18, 2012): 20 years after the film “A River Runs Through It," a river of tourism runs through Montana. The Oregonian. Retrieved from http://www.oregonlive.com/outdoors/index.ssf/2012/08/20_years_after_the_film_a_rive.html (Accessed: March 5, 2017).

El Clúster celebra el nuevo impulso a los rodajes en las Islas (May 25, 2017): Canarias7. Retrieved from: https://www.canarias7.es/cultura/cine/el-cluster-celebra-el-nuevo-impulsoa-los-rodajes-en-las-islas-JN935694 (Accessed: May 27, 2017).

García Aller, M. (November 5, 2015): El jefe de Netflix: "Las series no son un fenómeno temporal”. El Mundo. Retrieved from: http://www.elmundo.es/papel/lideres/2015/11/05/563b342e46163f1d088b458b.html (Accessed: February 28, 2017).

Girvin, S. (July 11, 2016): Game of Thrones brings estimated $£ 150 \mathrm{~m}$ to Northern Ireland. $B B C$. Retrieved from: http://www.bbc.com/news/uk-northern-ireland-36749938 (Accessed: June 2, 2017).

Haughney, C. (May 24, 2013): A Castle Becomes a Cash Register. The New York Times. Retrieved from: http://www.nytimes.com/2013/05/26/fashion/trying-to-turn-a-castle-into-a-cashregister.html (Accessed: March 13, 2017).

Jiménez, D. (November 22, 2014): El 'boom' del cine en Canarias, ¿̨un espejismo? El Diario. Retrieved from: http://www.eldiario.es/canariasahora/premium_en_abierto/boom-cine-Canarias-espejismo_0_325817779.html (Accessed: April 28, 2017).

Lennon, H. (October 30, 2015): Scots tourism feels 'Outlander effect' of hit TV show. The Scotsman. Retrieved from: http://www.scotsman.com/heritage/people-places/scots-tourism-feels-outlander-effect-of-hit-tv-show-1-3933138 (Accessed: March 13, 2017).

Poldark's Levant Mine parking fees defended by National Trust (February 16, 2017): BBC. Retrieved from: http://www.bbc.com/news/uk-england-cornwall-38984560 (Accessed: March 13, 2017).

Sanz, D. (May 9, 2017): Transvulcania convoca a la élite mundial del 'trail' en La Palma. Diario de Avisos. Retrieved from: http://diariodeavisos.elespanol.com/2017/05/transvulcania-convoca-la-elite-mundial-del-trail-la-palma/ (Accessed: May 20, 2017).

The SMell of COMMerce: How COMPANies use SCEnTS to Sell their Products (August 15, 2011): The Independent. Retrieved from: http://www.independent.co.uk/news/media/advertising/ the-smell-of-commerce-how-companies-use-scents-to-sell-their-products-2338142.html (Accessed: March 25, 2017) 
Tenerife bate en 2016 el ReCord de RODAJes aCogidos en un SOlo año (March 6, 2017): Diario de Tenerife. Cabildo de Tenerife. Retrieved from: http://www.diariodetenerife.info/tenerifebate-2016-record-rodajes-acogidos-solo-ano/ (Accessed: April 5, 2017).

Warren, J. (January 12, 2015): Tourism boom in TV drama towns. Sunday Express. Retrieved from: http://www.express.co.uk/news/uk/551448/Tourism-booms-towns-where-popularTV-dramas-set (Accessed: March 13, 2017).

Yoshida, E. (March 4, 2015): Apple had the most product placement in the films of 2014. The Verge. Retrieved from https://www.theverge.com/2015/3/4/8147063/apple-transformers-age-of-extinction-product-placement (Accessed: March 25, 2017).

\section{WEBGRAPHY}

Beard, H, (2014): The Borgen Effect. Retrieved from: http://www.travelmole.com (Accessed: March 16, 2017)

Canalis, X. (December 4, 2013): Turismo cinematográfico: 30 casos que han impulsado destinos. Hosteltur. Retrieved from: https://www.hosteltur.com/125790_turismo-cinematografico-30-casos-han-impulsado-destinos.html (Accessed: March 5, 2017)

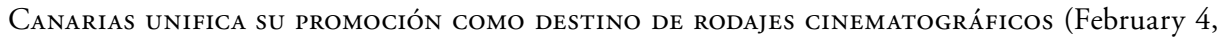
2016): Gobcan.es. Retrieved from: http://www.gobcan.es/noticias/lanzadera/69040/canarias-unifica-promocion-exterior-destino-rodajes-cinematograficos (Accessed: May 26, 2017)

Cooper, J.O. (September 1, 2015): 40 Million tourists choose their destination primarily by movies or TV programs they've seen. Afci.org Retrieved from: http://www.afci.org/news/40million-tourists-choose-their-destination-primarily-movies-or-tv-programs-they've-seen (Accessed: March 4, 2017).

Domínguez, J. (August 17, 2015): 'Juego de Tronos': El rodaje en España impulsa la economía local. Fotogramas. Retrieved from http://www.fotogramas.es/series-television/Juego-de-Tronosel-rodaje-en-Espana-impulsa-la-economia-local (Accessed: June 2, 2017).

Dudovskiy, J. (June 20, 2012): Product Placement as an Effective Marketing Strategy. Research Methodology. Retrieved from: http://research-methodology.net/product-placement-andbrand-placement/ (Accessed: March 25, 2017).

EvoluCión DEL PERFIL DEL TURISTA (2015): Retrieved from: http://www.turismodecanarias.com/ promoturturismocanarias/wp-content/uploads/2016/04/Promotur_Islas-Canarias_evolución_11-15.pdf (Accessed: May 20, 2017).

JANE (2016): Game of Thrones Holiday Destinations. Retrieved from: http://www.windublog.es.blog (Accessed: June 2, 2017).

McCarthy, N. (April 13, 2015): The Most Successful Movie Franchises In History [Infographic]. Forbes. Retrieved from https://www.forbes.com/sites/niallmccarthy/2015/04/13/ the-most-successful-movie-franchises-in-history-infographic/\#2204917c5d22 (Accessed: March 13, 2017).

Olsberg•SPI (2007): How Film and Television Programmes Promote Tourism in the UK. Retrieved from: http://www.bfi.org.uk/sites/bfi.org.uk/files/downloads/stately-attraction-2007-08. pdf (Accessed: March 13, 2017). 
OlsberG•SPI (2015): Quantifying Film and Television Tourism in England. Retrieved from: http://applications.creativeengland.co.uk/assets/public/resource/140.pdf(Accessed: March 13, 2017).

Pinchefsky, C. (December 14, 2012): The Impact (Economic and Otherwise) of Lord of the Rings/The Hobbit on New Zealand. Forbes. Retrieved from https:/www.forbes.com/sites/ carolpinchefsky/2012/12/14/the-impact-economic-and-otherwise-of-lord-of-the-ringsthehobbit-on-new-zealand/\#4def1c9931b6 (Accessed: June 2, 2017).

Quintero, S. (2016): Datos Económicos. Canarias: set de rodaje “low cost”. Retrieved from: https:// canariassetderodajelowcost.wordpress.com/datos-economicos/ (Accessed: April 28, 2017).

Roesch, S. (2016): Survey "Film Tourism in the Golden Age of Television”. AFCI.org. Retrieved from: http://afci.org/sites/default/film_tourism_survey_afci_stefan_roesch.pdf (Accessed: April 2, 2017).

Sparre, M. \& Lind, J. (2011): The Millenium Report. Economic Impact and Exposure value for the Stockholm region in the Swedish Milleniun feature film. Cloudberry Communication. Retrieved from: https://es.slideshare.net/PerHolmlund/the-millennium-report-economic-value-for-stockholm (Accessed: March 16, 2017).

Tourism Satellite Account - Why Do We Have It and What Does it Do? (2011): World Tourism Organization. Capacity Building Program, Asia Workshop II. Retrieved from: http:// statistics.unwto.org/sites/all/files/pdf/unwto_tsa_1.pdf (Accessed: February 20, 2017).

Wojсік, J. (September 24, 2012): Why today's TV series are so great. ScienceNordic. Retrieved from: http://sciencenordic.com/why-todays-tv-series-are-so-great (Accessed: February 28, 2017).

\section{Audiovisual Sources}

The Most Epic Safety Video Ever Made (2014): New Zealand: Air New Zealand. Retrieved from: https://www.youtube.com/watch?v=qOw44VFNk8Y (Accessed: May 25, 2017)

\section{Complementary Sources}

https://www.slideshare.net/milosjan/film-tourism-in-britain (Accessed: March 13, 2017).

https://tourismni.com/Grow-Your-Business/screen-tourism/game-of-thrones/ (Accessed: June 2, 2017).

http://www.turismodecanarias.com/promoturturismocanarias/wp-content/uploads/2016/04/Ficha-evoluci\%C3\%B3n-EGT-06-15.pdf (Accessed: May 20, 2017).

http://www.trainingnonstop.com (Accessed: May 23, 2017).

http://www.holaislascanarias.com/canary-way-surf (Accessed: May 23, 2017). 